\title{
Australian Retail Banking Customers' Perceptions of Time in A Service Recovery Process
}

\author{
Fredy-Roberto Valenzuela \\ University of New England \\ E-Mail: fvalenz2@une.edu.au \\ Ray Cooksey \\ University of New England \\ E-Mail: rcooksey@une.edu.au
}

\begin{abstract}
Results of past studies related to the role of time in service recovery processes have not been conclusive. The present study seeks to address this gap in the literature. In particular, the investigation is aimed at understanding how much time customers expect banks to take in solving their complaints, as well as how much personal time and effort customers are willing to invest during the process of addressing a complaint. To address these objectives, 25 in-depth interviews were conducted with Australian retail banking customers. Results demonstrated that a majority of customers expected banks to resolve their complaints within 24 hours, and that the amount of personal time and effort they were willing to invest in the process of complaining was dependent on the magnitude of the service failure. The investigation also identified four distinct groups of customers in relation to the personal time and effort they were willing to invest in the complaint process: non-complainers, convenience-oriented solution seekers, control seekers and desperate solution seekers.
\end{abstract}

Keywords: Service Recovery, Service Failures, Time Perception, Complaining Behaviour, Retail banking, Qualitative Methods

\section{INTRODUCTION}

This research will address the significant problem of how to conceptualize and theorize time in a service recovery event. There is consensus among researchers that the perception of time has a great impact on consumers' decision-making processes 
(Baker \& Cameron, 1996), and that customers' perception of time will not only affect their evaluations of service experiences, but will also impact their future decisions, such as whether or not to continue doing business with an organization (Bates et al., 2006). However, there is no consensus as to how to conceptualize and theorize time in consumer research (Bettany \& Gatrell, 2009, p. 294).

In relation to service recovery, there is consensus among researchers regarding the fact that for a variety of reasons, not all customers complain when they are dissatisfied, believing that it takes too much time, and, even worse, that it is a waste of time (Andreassen, 1988). However, past research has not been conclusive regarding the impact of time on customer evaluations of service recovery efforts (Davidow, 2003). Some researchers have found that timeliness has an impact on service recovery evaluation and customer post-complaint behaviour while others have not (Estelami, 2000). Several factors explain these varying results, such as the different cultural background of respondents in those studies (e.g., some studies were conducted in developed and others in developing countries) and the fact that different variables/items were used to measure time (Davidow, 2003).

Fairness theory is a well-established phenomenon in service recovery literature which explains how consumers evaluate recovery efforts of service providers, including banks, following a service failure. One of the three well-known dimensions of fairness theory is procedural fairness, of which speed of recovery is a major element. Despite the fact that there are many studies available which investigate how consumers evaluate these three dimensions, academic scrutiny of individual elements such as time perception of service recovery has not been sufficient. Additionally, past research has focused only on the time businesses take to resolve complaints, and not on the personal time and effort customers invest in looking for a solution to the complaint. Hence, both of these aspects of time perception, i.e. (a) how much personal time and effort customers are willing to invest during the complaining process, and (b) how much time customers expect banks to take to solve their complaints, need to be researched further to enrich the existing literature on customer complaint behaviour and the overall evaluation of service recovery efforts.

This study aims to contribute to the limited literature by exploring both aspects of time perception from Australian consumers' perspectives in the context of the banking industry. First, the study will discuss the nature of customers' expectations towards the speed of recovery efforts of Australian banks. It will then move on to discuss how much personal time and effort customers are willing to invest in achieving a resolution during the complaining process. Following this, the paper will explore a typology of customers in relation to their willingness to invest personal time and effort during the 
complaining process. Finally, the paper will include a discussion of conclusions and recommendations for future research.

\section{LITERATURE REVIEW}

Failures are inherent in the services industry, and customers perceive service failures when service performance fails to meet customer expectations (Dasu \& Rao, 1999). Gronroos (2007) states that service recovery aims to rectify problems in two potential situations: first, during the service encounter before customers complain, and secondly, after the service encounter if something went wrong and customers are dissatisfied about it. Service providers need to solve such problems through the service recovery process to restore customer trust (Sharma, Medury, \& Gupta 2012). Unsatisfactory recovery efforts will produce negative consequences, such as customer dissatisfaction, defection and negative word-of-mouth (WOM) publications (Chang, 2006; Vázquez, Suárez \& Díaz, 2010). For example, Casado, Nicolau, and Mas (2011) found compelling evidence of the potentially damaging impact of service failures followed by ineffective or non-existent service recoveries in the context of the banking industry in Spain. According to Dasu and Rao (1999), customers generally do not expect services to be perfect, and "it is not the initial failure to deliver the core service alone that causes dissatisfaction, but rather the employee's response to the failure" (Bitner, Booms \& Tetreault, 1990, p. 80). Keaveney (1995) also asserts that service recovery failures are one of the major causes behind consumers' decisions to exit a service. Similarly, a positive association between service recovery, customer satisfaction and loyalty is a well-established phenomenon in the service recovery literature, including the banking sector (Johnston \& Michel, 2008; Kau \& Loh, 2006; Osarenkhoe \& Komunda, 2012; Younas \& Jan, 2012).

Service recovery has been defined as actions undertaken by service providers to address service failures and the set of processes that firms employ to attempt to provide a remedy for those failures (Battaglia, Borchardt, Sellitto, \& Pereira 2012; Kelley \& Davis, 1994). Smith, Karwan, and Markland (2012) suggest that service providers should have a complete recovery system, because such a system has a significant impact on customer satisfaction and market performance of the service provider. According to Bowen and Johnston (1999), service recovery is the second opportunity a business has to make things right for a customer, as the first time the business failed to do so in a proper way. People are increasingly demanding of refunds, exchanges and replacements when they face a service failure (Kelley, Hoffman, \& Davis, 1993). These expectations shape their evaluation of service recovery efforts (Bhandari, Tsarenko, \& Polonsky, 2007). Fairness or justice theory of 
service recovery is the most adopted version by scholars to explain customer expectations and their evaluation of service recovery efforts. It demonstrates three aspects of fairness in service recovery: distributive justice, procedural justice and interactional justice. Procedural justice refers to the methods the firm uses to deal with the problems arising during service delivery in aspects such as accessibility, timing/speed, process control, delay and flexibility to adapt to the consumer's recovery needs, while interactive justice includes customers' perceptions about employees' empathy, courtesy, sensitivity, treatment and the effort they expend to solve the problem (Del Río-Lanza, Vázquez-Casielles, \& Díaz-Martín, 2009). Distributive justice refers to the perceived fairness of the remedy offered by the service provider (Blodgett, Hill, \& Tax, 1997). A large number of studies are available which have investigated the impact of these three elements on customer satisfaction and various behavioural outcomes (for example, Andaleeb, Huda, Akhtar, \& Dilshad, 2012; Battaglia, et al. 2012; Blodget, et al., 1997; Casado, et al., 2011; Gelbrich \& Roschk, 2011; Gustafsson, 2009; del Río-Lanza et al., 2009; and Sabharwal \& Soch, 2011).

To date, service recovery research has focused more heavily on developing an overall framework for measuring customer evaluations of service failures, but it does not focus on specific elements of service recovery dimensions (Zhou, Tsang, Huang, $\&$ Zhou, 2012). Time factor is a major element that customers take into consideration when evaluating service recovery efforts, since speed of recovery is a major aspect of procedural justice (Tax, Brown, \& Chandrashekaran, 1998). There are two opposing views of time that service providers must take into consideration when resolving complaints, i.e. a quick resolution and a delaying resolution (Zhou, et al., 2012). A number of studies support the argument for speedy recovery (Brock, 1974; Chebat \& Slusarczyk, 2005; Clark, Kaminski, \& Rink, 1992; Fenvessy, 1972; Gilly \& Gelb, 1982; Mattila \& Mount, 2003; Ramsey, 2003; Taylor, 1994; Wirtz \& Mattila, 2004). For example, Clark, et al. (1992) found that a quick response to complaints has a positive impact on corporate image. Boshoff (1997) revealed that speed of recovery is the second most important aspect, followed by level of atonement, which has a positive impact on customer satisfaction. Similarly, Taylor (1994) asserts that longer delays lead to lower evaluations of service. Thus, overall evaluations of service were directly affected by evaluations of punctuality and the uncertainty and anger created by the delays. Mattila and Mount (2003) also found that satisfaction with problem handling and repurchase intentions are directly related to the time taken to respond to email complaints. According to Wirtz and Mattila (2004), compensation may not enhance recovery satisfaction when quick resolution with an apology is present, and, 
similarly, compensation cannot lessen dissatisfaction when there is a delayed response. Ramsey (2003) argues that response time is critical in dealing with complaints. Thus, no complaints should go unattended for more than 24 hours. According to Chebat and Slusarczyk (2005), 'timeliness' is a basic requirement in solving problems; hence, slow recovery may generate negative emotions. However, Dube-Rioux, Schmitt, and Leclerc (1989) revealed that consumers who encounter a delay during the pre-process and post-process phase will evaluate the service more negatively than customers who experience a delay during the in-process phase.

In contrast to the above arguments for a speedy recovery, some scholars argue for delaying complaint resolutions for better customer evaluations (Blodgett et al., 1997; Davidow, 2003; Karatepe \& Ekiz, 2004). For example, Blodgett et al. (1997) demonstrated that timeliness did not have a significant effect on repatronage intentions and negative word-of-mouth intentions. Gilly and Gelb (1982) revealed that speed of recovery is not important when a monetary loss was involved. Hence, Davidow (2003) put forth three propositions based on a review of complaint handling literature: (a) reasonable response speed may only be important in nonfinancial lossrelated complaints (b) timeliness may only be a critical factor after an unreasonable delay, and (c) acceptable response time is context-specific and mode-specific. Karatepe and Ekiz (2004) also found similar results, which revealed that there was no significant relationship with promptness in compiling handling and complaint satisfaction information.

The two above-referenced opposing views suggest that past research has not been conclusive regarding the impact of time on customer evaluations of service recovery efforts. It is possible that past research arrived at different conclusions because customers might have interpreted the concept of time in different ways. For example, some scholars argue that customer expectations of service recovery, including the speed of recovery, are dependent upon various moderating factors. Such factors include past experiences with the service provider (Singh, 1990), the extent of the relationship with the service provider (Halinen \& Tahtinen, 2002), magnitude or severity of the problem (Weun, Beatty, \& Jones, 2004; Smith, Bolton, \& Wagner, 1999), and the availability of alternative providers (Colgate $\&$ Norris, 2001). Zhou et al. (2012) also found that in a non-separated service's failure, where production and consumption take place simultaneously, an immediate resolution produces better customer evaluations than a delaying resolution. However with regard to a separated service's failure, a delaying resolution produces better results than an immediate resolution. Similarly, Miller, Kahn, and Luce (2008) found that customers' evaluations of waiting times are moderated by an individual's coping strategies. For 
example, a shortened waiting time may increase stress among consumers who use approach-oriented coping strategies. In addition, customer expectations may differ across different industries (Bejou \& Palmer, 1998; Schroefer \& Ennew, 2002) and may be influenced by culture as well (Kanousi, 2005). Hence, more research is essential to better understand this phenomenon. Specifically, greater attention should be paid to understanding the various moderating effects, such as magnitude of the problem and cultural influences. More industry-specific and country-specific investigations may produce better insights into this research issue. For example, no studies have been undertaken on how customers evaluate waiting time and what factors influence that perception in the context of the Australian banking industry. Hence, this paper aims to contribute to the gap of this literature by addressing the following research equation:

What is the nature of customers' expectations towards speed of recovery efforts of Australian banks?

Customers' complaining behaviour has also been an important area of research, because past research has shown that a small percentage of customers tend to complain after a service failure. Chakrapani $(1998$, p. 12) claims that only $4 \%$ of dissatisfied customers make complaints, while other researchers argue that up to twothirds of dissatisfied customers take no action (Richins \& Verhage, 1985). Given the prevalence of non-complaining customers, past research has tried to understand those factors which may trigger this non-complaining behaviour of many customers. For example, Al-Foqahaa (2010) found that customers' complaining behaviour is negatively affected by lack of information as to whom they should complain to, perceived justice, and the expected costs and efforts of complaining in Palestine. In addition, customers' educational level, frequency of bank visits, and the type of problem were also found to have an impact on complaining behaviour, while sex, age and income were found to have no effect (Al-Foqahaa, 2010). Lala and Priluck (2011) undertook a study to investigate those circumstances which lead students to complain, and they found that perceived severity of the problem, perceived ease of complaining (need to put in a minimum effort), and the belief in a positive response from the school have a positive impact on their intention to lodge complaints.

Similarly, Bolfing (1989) found that customers tend to complain more when the problem is sufficiently severe, and if they are encouraged to take an active role in service management but may engage in more harmful negative WOM if service firms set up barriers to the complaint process. According to Bolfing (1989, p.7), the nature of the consumption experience problem may affect the effort that customers make in expressing their dissatisfaction: 
First, the lower the satisfaction with a service encounter, the stronger the consumer outburst. Second, the more important the usage experiences to the customer and the more costly the poor service delivery, the more effort the customer will expend. Third, if the customer senses that playing an active role in the service interaction is desired and rewarded, strong customer effort in expressing dissatisfaction will be forthcoming.

Hence, Bolfing concludes that perceived severity of the problem and perceived probability of receiving a positive outcome are strong predictors of consumers' willingness to lodge complaints.

Lewis and Spyrakopoulos (2001) argue that customers with long relationships or high deposits with their banks are more demanding with respect to service recovery. Thus, highly loyal customers have a greater intention of making complaints than less loyal customers when a service failure occurs (Namkung, Jang, \& Choi, 2011). Customers' nature of coping with service failures can also influence their intention to lodge complaints, because complaining is an extension of their way of coping with the service incident (Chebat \& Slusarczyk, 2005). Chebat \& Slusarczyk, 2005) pointed out that emotions can also play a role in determining the complaint behaviour of consumers through the nature of coping with service failures. They found that three emotions measured in their study (anger/disgust, anxiety/ surprise, resignation/sadness) have a significant impact on the cognitive appraisal of the problem and the coping behaviour following service failures. According to Tsarenko and Strizhakova (2012), active and expressive coping, which has a positive association with the emotional intelligence of customers' behaviour, leads to more complaining, while denial coping has a negative impact on complaining behaviour. Bolfing (1989) also found that customers' self-confidence and assertiveness influence complaining behaviour. According to Mittal, Huppertz, and Khare (2008), complaining is more likely when the tendency for information control is stronger and the strength of ties with service employees is weaker. In line with these findings, other studies have shown that there is a relationship between complaining and individual characteristics of complainants (e.g., demographic variables, personality, and personal values), product attributes, and attitudes towards complaining (Andreasen, 1988; Bearden \& Mason, 1984; Bolfing, 1989; Day \& Lando, 1977; Heung \& Lam 2003; Jacoby \& Jaccard, 1981; Keng, Richmond, \& Han, 1995; Kolodinsky, 1992; Morganosky \& Buckley, 1987; Singh, 1990).

Despite the fact that ample studies are available which examine those factors influencing customer complaining tendencies, no studies are available in the extant literature that address how much effort and time customers are willing to spend on 
lodging a complaint. Academicians are uncertain about issues such as whether all customers follow a similar process of complaining and what factors influencing customers' willingness to invest time and effort into complaining. The present knowledge on these issues, and especially academic scrutiny of whether service providers can segment the market based on different complaining processes if they exist, are not adequate to provide sufficient guidelines for practitioners. This is very true in the context of Australian customers' complaining behavior, particularly in the banking industry in Australia. Hence, the following research question is addressed by the present study in order to enrich the existing limited knowledge on those issues:

How much personal time and effort are customers willing to invest in achieving a resolution during the complaining process?

Several researchers have tried to categorize customers depending on their complaining behaviour. For instance, Siddiqui and Tripathi (2010) found four segments of customers in terms of their complaining attitude in the context of the Indian banking sector: non-complainers, switchers, prompt complainers and positive thinkers. Non-complainers tend not to complain because they do not know where and how to complain. The other three segments correspond to customers who tend to complain in different ways: Switchers tend to complain immediately and to switch to another bank if the problem is not resolved; prompt complainers tend to complain promptly, and they switch banks only if they are required to complain several times; and positive thinkers evaluate very highly banks' service recovery efforts and have a higher level of acceptance of banks' mistakes. In relation to the time customers spend during the complaining process, it could be argued that customers belonging to each of these segments would spend a different amount of time looking for a solution to their complaints. For instance, non-complainers would spend no time at all during this process, while switchers would spend little time looking for a solution to their complaints. This investigation also aims to explore how much time and effort each of these segments is willing to spend to make complaints, and if a different classification of customers is required. This investigation also aims to explore how much time and effort each of these segments is willing to spend to make complaints, and if a different classification of customers is required. Hence, the following research question is addressed by the present research:

Can a typology of customers be identified in relation to their willingness to invest personal time and effort during the complaining process?

In summary, this paper strives to contribute to the existing gap in the extant literature regarding how to conceptualize and theorize time in consumer research by addressing issues related to the nature of customers' expectations towards speed of 
recovery efforts of Australian banks and how much personal time and effort customers are willing to invest in achieving a resolution during the complaining process, and by proposing a typology of customers in relation to their willingness to invest personal time and effort during the complaining process.

\section{METHODOLOGY}

The investigation employed one-on-one semi-structured, in-depth qualitative interviews. In this investigation, qualitative-focused interviews were conducted because this method allowed the researcher to both "probe" interviewees and gain their undivided attention. Following the interview style recommended by Minichielo et al. (1999:34-35), interviewers adopted a conversational rather than an interrogative style of questioning. They focused on motivating customers to recall, reveal and construct aspects of subjective experiences and interpretations and making discussions coherent and meaningful. Despite the importance of maintaining a conversational style, some semi-structured questions were used to maintain the pace and flow of the interview and to help the informant remain focused. Such a semi-structured approach was helpful in adhering to the time frame set for interviews (Minichielo et al., 1999:39). To obtain information relative to service recovery processes, and in particular, to issues related to perception of time, respondents were asked three different types of questions: (a) overall comments about past complaining experiences; (b) perception of time in service recovery process; and (c) different methods of communication during the complaining process.

The number of participants interviewed was 25. Participants for the study were chosen using 'purposive sampling.' After conducting 20 interviews, convergence of opinions amongst the respondents began to surface; hence, the information obtained was considered sufficient to address the goal of this study. However, as recommended by Yanamandram and White (2006), even though convergence started to occur at the 20 -interview mark, an additional five qualitative-focused interviews were undertaken to decrease the chance of new information being missed. Purposive sampling was the best option for this exploratory study, since it involved the targeted selection of participants who could provide rich data on the research issue (Patton, 1990). The participants were sourced from inhabitants of Australia and the cities of Sydney, Melbourne and Armidale. The main criteria for inviting participation in the study among potential participants were: (a) to be over 18 years of age, (b) to be a customer from the retail banking industry (e.g., to have a credit card, mortgage, etc.), and (c) to have experienced a service failure with their bank. 
Thematic content analysis was undertaken to explore the themes and issues emerging from the data. The approach was inductive in nature, allowing the data to reveal themes and relevant constructs and associations amongst those constructs. The constant comparative technique was employed simultaneously with data collection in order to facilitate more rigorous analysis. This technique involved reading and rereading transcripts along with emerging new data in order to find and refine the themes and categories. Qualitative data analysis software (MAXQDA 10 Plus) was employed to manage the process of analysis since sample size was comparatively large.

In relation to the interview process, before undertaking the in-depth interviews, approval was obtained from the UNE Human Research Ethics Committee (HE12086). To select participants, potential participants' contact details were gathered using personal contacts, official websites of companies and professionals which provide contact details, and visiting cards of prospective participants collected by personally visiting their offices. Only publicly listed contact details were used. After collecting the contact details, the researcher emailed prospective participants, explained the nature and purpose of the study, and requested the prospective participant for an interview at a later time. If the prospective participant expressed his or her willingness to participate, the researcher provided the information sheet and arranged a convenient time and place for the interview (e.g., their offices or home). A consent form was given to the participant before the commencement of the interview so that the participant could choose to participate by signing the consent form or by recording their informed consent at the beginning of the interview. Fifty percent of the interviews were conducted face-to-face and digitally recorded, with informed consent from the participant. The rest of the interviews were undertaken using Skype. The average length of each interview was 25 minutes. Once all the interviews were finished, each interview was transcribed (verbal content only) and stored in a Word document. This process was undertaken by two researchers in order to make sure no mistake was made and that the transcripts were $100 \%$ accurate.

\section{FINDINGS}

Twenty-five qualitative-focused interviews of Australian customers in the retail banking industry were conducted in order to determine the dimensions that are important for them when evaluating bank service recovery efforts and to obtain information regarding their switching behaviour. Fifteen out of 25 of the customers who were interviewed were male. A range of interesting results were obtained from 
the investigation, which addressed each of the three research questions discussed earlier. A summary of the findings follows.

\section{Australian Customers' Expectations of Waiting Time Needed For Complaint Resolution}

The literature has suggested that the speed of recovery is one facet of the recovery process which has a significant bearing on customer satisfaction. This is a passive form of time passage referring to the elapsed waiting time between complaint submission and complaint resolution by the bank. Findings showed that participants had different expectations about the time that the banks required to take to solve the problems. For example, six participants held the view that banks should resolve the problem within 24 hours, whereas five participants said problems should be resolved in just five minutes. Some participants said they were even willing to wait two weeks.

However, as can be seen in Table 1, customers' time perceptions may vary based on several factors, i.e. magnitude/complexity of the problem, amount of money involved, perceived urgency of the problem and various other factors, such as whether the bank provided a realistic time framework to resolve the problem, and periodic updates on the progress of the resolution. For example, the majority (20) agreed that their time perception might depend upon the nature of the problem (magnitude or complexity of the problem). That is, they were willing to wait for a comparatively long time if the problem was significant and complex, and vice versa.

\section{Personal Time and Effort That Australian Customers are Willing to Invest in the Complaining Process}

The study also made an effort to explore the amount of time and effort that Australian customers are willing spend in the complaining process. As can be seen in Tables 2 and 3, a few participants (2) expressed their unwillingness to invest time and effort to lodge complaints, simply because it is either not a worthwhile action or an unnecessary stress or tension. For example:

We recently booked a holiday, and we asked them to change the name. John's name was spelled wrong. So we had to get through some hassle to get that changed. We just got a letter from them and some pamphlets. The name is still wrong after calling them twice. It's like, why is it still wrong? The postage system doesn't talk to them. This is just stupid. It just annoys me. Why do I have to do this? Why do I have to waste time to fix a small problem? It's just time (participant \#25). 
Table 1 Factors that Influenced Customers' Waiting Time Perceptions

\begin{tabular}{|c|c|c|c|}
\hline & Factor & $\begin{array}{c}\text { Number of } \\
\text { participants }\end{array}$ & $\begin{array}{c}\text { Number of references in } \\
\text { interviews }\end{array}$ \\
\hline & Magnitude/Complexity of the problem & 20 & 26 \\
\hline & $\begin{array}{l}\text { - More waiting time if the problem was complex } \\
\text { or severe }\end{array}$ & 15 & 16 \\
\hline & $\begin{array}{l}\text { - Less waiting time if the problem was simple and } \\
\text { minor (trivial issues) }\end{array}$ & 11 & 13 \\
\hline \multirow[t]{9}{*}{ (b) } & Amount of money involved & 8 & 10 \\
\hline & $\begin{array}{l}\text { If more money } \rightarrow \text { more waiting time; less money } \\
\rightarrow \text { less waiting time }\end{array}$ & 6 & 8 \\
\hline & $\begin{array}{l}\text { If more money } \rightarrow \text { less waiting time (quick } \\
\text { resolution) }\end{array}$ & 2 & 3 \\
\hline & $\begin{array}{l}\text { Urgency of the problem (if it was more urgent } \rightarrow \\
\text { less waiting time) }\end{array}$ & 5 & 7 \\
\hline & Other factors influencing waiting time perceptions & & \\
\hline & $\begin{array}{l}\text { Willing to wait more time if properly informed } \\
\text { about the process at first (setting realistic } \\
\text { expectations by providing explanations) }\end{array}$ & 4 & 5 \\
\hline & $\begin{array}{l}\text { Willing to wait more time when there was an } \\
\text { assurance of a positive outcome }\end{array}$ & 4 & 5 \\
\hline & $\begin{array}{l}\text { Willing to wait more time if being updated the } \\
\text { progress }\end{array}$ & 4 & 5 \\
\hline & Situational factors & 3 & 3 \\
\hline
\end{tabular}

\section{Typology of Customers on the Basis of Their Complaining Behaviour}

Following the segmentation created by Siddiqui and Tripathi (2010), first respondents were classified into non-complainers and complainers.

- Non-complainers

This category included those participants who were not willing to complain (two participants) at all. For instance, one respondent stated: If something goes wrong I just move on (participant \#23).

- Complainers

This category included those participants who were willing to complain (23 participants). These customers might complain in different ways. For instance, a respondent mentioned: I just prefer to call. I try to avoid the travel because I have to spend much more time in that case. I don't want to spend more than five minutes (participant \#5).

As mentioned earlier, Siddiqui and Tripathi (2010) subdivided the complainers into three segments: switchers, prompt complainers and positive thinkers. It was not possible to determine how much time each of these groups is willing to spend during 
the complaining process. However, based on the themes that emerged from the interviews, the investigation managed to divide the complainers into three different types of customers in relation to the amount of personal time and effort they were willing to put/spend during the service recovery process. These segments were named: 'convenience-oriented solution seekers,' 'greater control seekers' and 'desperate solution seekers.'

- Convenience-oriented solution seekers

This category included customers who were willing to expend limited personal time and effort - for example, making complaints over the phone or by email, but making no further deliberate efforts to resolve the problem. This category comprised three participants. Their problems were either minor or not very urgent issues. For instance, one respondent stated: Sometimes I prefer to write an email. That is handy. You can do that without traveling or going anywhere. That's how I prefer usually to lodge any complaint (participant \#4).

- Control seekers

This category includes those customers who wanted to have more control over the problem. For example, they directly visited the bank or directly contacted bank management. They tended to prefer to have face-to-face encounters when they complained and also tended to make formal complaints using the proper procedures (nine participants). They tried to address the problem at the right place the first time when they complain instead of making complaints two or three times or bringing the problem to a higher level the next time. Since they address the problem at the right place in the first step, they tend to show behavioural outcomes based on the outcomes of the complaint. For instance, one respondent stated: I usually go to the bank and try and negotiate with whoever is behind the counter for a reasonable outcome which I would expect to happen, given that we are all reasonable, I assume (participant \#7).

- Desperate solution seekers

This category includes those customers who tried to achieve a resolution through investment of considerable personal time and effort. For example, they may have first made the complaint over the phone or by email and then personally visited the bank if they had not received a fair response, and they may have even taken their complaint to higher level of management (11 participants). For instance, one respondent stated: I would make sure I have the correct information. Then I would ring the bank to speak to the person who looks after that section or who is representing that section of the bank. If I couldn't resolve it over the telephone, I 
would then make an appointment to go to the bank and talk to somebody in person at the bank. If I couldn't resolve it then, I would close my account and walk away from the bank (participant \#2).

Table 2 Personal Time Customers were Willing to Invest in The Complaining process

\begin{tabular}{|c|c|c|}
\hline $\begin{array}{l}\text { Personal time customers were willing to invest in the } \\
\text { complaining process }\end{array}$ & $\begin{array}{l}\text { Number of } \\
\text { participants }\end{array}$ & $\begin{array}{l}\text { Number of } \\
\text { references in } \\
\text { interviews }\end{array}$ \\
\hline
\end{tabular}

(a) Not worth investing any time in complaining 3

(b) Minimum time invested in complaining $\quad 5 \quad 7$

(c) Only few minutes $\quad 3 \quad 5$

(d) Only few hours $\quad 1 \quad 1$

(e) Depended on the magnitude or the severity of the $12 \quad 16$ problem/complaint

- No complaint for trivial matters $\quad 5 \quad 6$

- Less time on less important issues 3

- More time on more important/severe issues $\quad 7 \quad 8$

Table 3 Personal Effort Customers were Willing to Invest in The Complaining Process

\begin{tabular}{lcc}
\hline \multicolumn{1}{c}{ Customer Actions } & $\begin{array}{c}\text { Number of } \\
\text { sources }\end{array}$ & $\begin{array}{c}\text { Number of } \\
\text { references }\end{array}$ \\
\hline (a) Not worthwhile putting energy into complaining & 2 & 3 \\
(b) Not willing to experience stress or tension by complaining & 1 & 2 \\
(c) Change their buying behaviour instead of complaining & 1 & 2 \\
(d) Complaining to others (spouse and friends) instead of to & 1 & 2 \\
the organization & 6 & 7 \\
(e) Willing to put minimal effort e.g. just give a call only & 19 & 23 \\
(f) Depends on the magnitude or the severity of the & & 6 \\
problem/complaint & 5 & 8 \\
- No complaint for trivial matters & 8 & 19 \\
- Less effort for less important issues & 16 & 5 \\
- More effort for more important/severe issues & 3 & \\
(g) Depended on likely outcome (more effort if there was a & & \\
high likelihood of a positive outcome) & & \\
\hline
\end{tabular}

In summary, the investigation revealed promising results in relation to the amount of time and effort customers are willing to spend during the complaining process. Results of the investigation showed that several factors affect the amount of time and effort customers spend looking for a solution to their complaints, such as magnitude of the problem. In addition, findings showed that only a few customers 
were not willing to spend time and effort to lodge complaints. Finally, the research showed that customers might be classified into four segments in relation to the amount of time and effort they are willing to spend in the complaining process.

\section{CONCLUSIONS AND IMPLICATIONS}

This study critically analyzed a facet of Australian banking, i.e. customers' perception of time in the face of contemplating and making a complaint about a service failure. The study attempted to make a substantive contribution to the limited body of literature pertaining to this issue, especially in the Australian context. The indepth interviews that were conducted provided valuable insights into these matters and resulted in greater understanding of the issues that customers faced with the time associated with the complaining process and service recovery. A very important conclusion of this investigation is that participants distinguished between personal time and effort invested in seeking a resolution and waiting time. Waiting time reflected a passive solution-seeking process; personal investment of time and effort reflected an active solution-seeking process. Most participants shared views about both perspectives on time.

The second substantive finding in this study pertains to the expectations that Australian customers have of their banks when it comes to how long they must wait for their complaint to be resolved by the bank. The study showed that most of the participants interviewed wanted their problem to be solved within 24 hours. Some of the participants reported that they were not willing to wait more than five minutes, while a small number were willing to wait up to two weeks. When probed further on this issue, it was found that a vast majority of the participants (20) agreed that the time they were willing to wait was dependent upon the nature of the problem (its complexity and magnitude). They indicated that if the amount of money involved was relatively large and the problem was a non-routine one, then they would be willing to wait longer for it to be resolved. These findings are consistent with the previous research - for example, Smith, Bolton, and Wagner (1999), and Weun et al. (2004), which emphasise the severity of the problem as a major predictor of customers' perceptions of waiting time for a solution. Companies would do well to pay heed to this crucial finding and would be best served if they can prioritize the complaints based on their urgency, complexity, and relative importance.

The third issue addressed by the study was to ascertain how much personal time and effort Australian customers were willing to invest in the complaining process. A vast majority of the participants reported that the amount of personal time and effort they were willing to invest in the complaining process is dependent upon the 
magnitude of their problem and its importance. For minor and trivial problems, the amount of time and energy they were willing to spend is minimal. A few of the participants reported that they would abstain from complaining about minor and trivial matters since they viewed it as not being worth the trouble or the aggravation. Past research has also found similar evidence - for example, see Bolfing (1989) and Lala and Priluck (2011).

Whether or not all customers were willing to invest the same amount of personal time and effort in the complaining process was the final issue addressed in this study. We sought to classify customers on the basis of their complaining behaviour as reflected in their interviews. Four types of customers could be identified: non complainers; convenience-oriented solution seekers; control seekers; and desperate solution seekers. Expectations of service recovery were found to be different across these four groups. Thus, banks need to be able to identify which category each of their customers belongs to and cater to their needs accordingly. To do so, banks will need to gather information regarding customers' complaining behaviour, such as steps followed to lodge complaints and to seek a resolution to those complaints. The inherent differences in the traits of each of these types of complainers meant that a one-size-fits-all or undifferentiated strategy would not be effective. Hence, the findings of this study not only provide greater academic understanding of the complaining behaviour of Australian banking customers from a time perception perspective, but also provide useful insights for banks and practitioners which may influence and shape the strategies they develop to cater to their clientele. For instance, organizations could manage customers' expectations by designing clear mechanisms for lodging complaints and by establishing the exact number of hours that it would take to achieve a resolution. By doing so, customers would know exactly the steps they must follow to lodge a complaint so that they would not waste time in the process. In addition, customers would not need to worry about the complaint during the period of time established by the organization, removing the need for additional phone calls or visits to the bank to pursue the outcome of the complaint, and also reducing the levels of stress that customers might encounter when complaining.

In relation to implications for theory, results demonstrated that the service recovery dimension of 'time' has two different components or dimensions: the time banks take to solve the complaint (waiting time), and the personal time (and effort) that customers invest in looking for a resolution to the complaint. A failure to distinguish between these perspectives on 'time' may explain why past researchers have reached contradictory conclusions about the importance of time (Davidow, 2000, 2003). As discussed in the literature review, there is no consensus as to the effect of 
time on customer service recovery evaluation. Some studies have shown a positive effect. However, others have shown no effect at all. Future research, therefore, should make a very clear distinction between the perspectives of time being considered in a study, so that the conclusions drawn may be properly contextualized and compared with the findings of other investigations. Consequently, bank managers should determine which perspective of time is most critical to their customers in order to implement more appropriate customer complaint handling systems.

Regarding future research recommendations, and considering that this study was exploratory in nature, it is recommended that the findings of this investigation be validated. In particular, those findings related to the classification of customers based on their willingness to spend time and effort to make complaints should be validated. Cluster analysis or other segmentation techniques could be employed in order to accomplish this task.

\section{REFERENCES}

Al-Foqahaa, S. (2010). Situational Dimensions of Customers Complaining Behavior when Dissatisfied with Banking Services in Palestine. An-Najah University Journal for Research, 24(9), 2657-2690.

Andaleeb, S. S., Huda, S. S. M. S., Akhtar, A. \& Dilshad, S. (2012). Customer Satisfaction With Complaint Resolution in the Power Sector in a Developing Economy. Journal of Nonprofit \& Public Sector Marketing, 24, 181-201. http://dx.doi.org/10.1080/10495142.2012.705178

Andreassen, A. R. (1988). Consumer complaints and redress: what we know and what we don't know. In S. Maynes (Ed.), The frontier of research in the consumer interest, 675, 675-722.

Baker, J., and Cameron, M., (1996). "The effects of the service environment on affect and consumer perception of waiting time: An integrative review and research propositions", Journal of the Academy of Marketing Science 24 (4), 338-349.

Bates, D., Kukalis, S., and Dillard, J., (2006). "The impact of structural changes in leisure time on the perceptions of recreational activities: A United States survey", International Journal of Management, 23 (1), 86-94.

Battaglia, D., Borchardt, M., Sellitto, M. A., \& Pereira, G. M. (2012). Service recovery: a method for assessing performance. Business Process Management Journal, 18(6), 5-5. http://dx.doi.org/10.1108/14637151211283366

Bearden, W. O. \& Mason, J. B. (1984). An investigation of influences on consumer complaint reports. Advances in consumer research, 11, 490-495. 
Bejou, D. \& Palmer, A. 1998. Service failure and loyalty: an exploratory empirical study of airline customers. Journal of Services Marketing, 12, 7-22. http://dx.doi.org/10.1108/08876049810202339

Bettany, S., and Gatrell, C., (2009). "The present location of temporal embeddedness: The case of time linked consumption practices in dual career families", Advances in Consumer Research, Vol.36, MI: Association for Consumer Research, 293-99.

Bhandari, M. S., Tsarenko, Y. \& Polonsky, M. J. (2007). A proposed multidimensional approach to evaluating service recovery. Journal of Services Marketing, 21, 174-185. http://dx.doi.org/10.1108/08876040710746534

Bitner, M. J., Booms, B. H. \& Tetreault, M. S. (1990). The service encounter: diagnosing favorable and unfavorable incidents. The Journal of Marketing, 71-84. http://dx.doi.org/10.2307/1252174

Blodgett, J. G., Hill, D. J. \& Tax, S. S. (1997). The effects of distributive, procedural, and interactional justice on postcomplaint behavior. Journal of Retailing, 73, 185-210. http://dx.doi.org/10.1016/S0022-4359(97)90003-8

Bolfing, C. P. (1989). How do customers express dissatisfaction and what can service marketers do about it? Journal of Services Marketing, 3(2), 5-23. http://dx.doi.org/10.1108/EUM0000000002483

Boshoff, C. (1997). An experimental study of service recovery options. International Journal of service industry management, 8, 110-130. http://dx.doi.org/10.1108/09564239710166245

Bowen, D. E., \& Johnston, R. (1999). Internal service recovery: developing a new construct. International Journal of Service Industry Management, 10(2). http://dx.doi.org/10.1108/09564239910264307

Brock, L. A. (1974). Don't Bug the Consumer. Sales Management, 113, 48-49.

Casado, A. B., Nicolau, J. L., \& Mas, F. J. (2011). The harmful consequences of failed recoveries in the banking industry. International Journal of Bank Marketing, 29(1), 32-49. http://dx.doi.org/10.1108/02652321111101365

Chakrapani, C. (1998). How to Measure Service Quality and Customer Satisfaction, American Marketing Association, Chicago.

Chang, C. C. (2006). When service fails: The role of the salesperson and the customer. Psychology and Marketing, 23(3), 203-224. http://dx.doi.org/10.1002/mar.20096

Chebat, J. C., \& Slusarczyk, W. (2005). How emotions mediate the effects of perceived justice on loyalty in service recovery situations: an empirical study. Journal of Business Research, 58(5), 664-673. http://dx.doi.org/10.1016/j.jbusres.2003.09.005 
Clark, G. L., Kaminski, P. F., \& Rink, D. R. (1992). Consumer complaints: advice on how companies should respond based on an empirical study. Journal of Consumer Marketing, 9(3), 5-14. http://dx.doi.org/10.1108/08876049210035755

Colgate, M. \& Norris, M. (2001). Developing a comprehensive picture of service failure. International Journal of service industry management, 12, 215-233. http://dx.doi.org/10.1108/09564230110393211

Day, R., \& Lando, E. (1977). Toward a theory of consumer complaint behaviour. In A. Woodside, J. Seth \& P. Bennet (Eds.), Consumer and Industrial Buying Behaviour. New York: North Holland.

Dasu, S. \& Rao, J. (1999). Nature and determinants of customer expectations of service recovery in health care. Quality Management in Health Care, 7, 32-50. http://dx.doi.org/10.1097/00019514-199907040-00007

Davidow, M. (2000). The bottom line impact of organizational responses to customer complaints. Journal of hospitality \& tourism research, 24(4), 473-490. http://dx.doi.org/10.1177/109634800002400404

Davidow, M. (2003). Organizational responses to customer complaints: what works and what doesn't. Journal of service research, 5, 225-250.

Del Río-Lanza, A. B., Vázquez-Casielles, R. \& Díaz-Martín, A. M. (2009). Satisfaction with service recovery: Perceived justice and emotional responses. Journal of Business Research, 62, 775-781. http://dx.doi.org/10.1016/j.jbusres.2008.09.015

Dube-Rioux, L., Schmitt, B. H., \& Leclerc, F. (1989). Consumers' reactions to waiting: when delays affect the perception of service quality. Advances in consumer research, 16(1), 59-63.

Estelami, H. (2000). "Competitive and procedural determinants of delight and disappointment in consumer complaint outcomes", Journal of Services Research, 2(3), 285-300. http://dx.doi.org/10.1177/109467050023006

Fenvessy, S. J. (1972). How to Handle Customer Complaints. Sales Management, 108, 34-39.

Halinen, A. \& Tähtinen, J. (2002). A process theory of relationship ending. International Journal of service industry management, 13, 163-180. http://dx.doi.org/10.1108/09564230210425359

Heung, V. C. S., \& Lam, T. (2003). Customer complaint behaviour towards hotel restaurant services. International Journal of Contemporary Hospitality Management, 15(5), 283-289. http://dx.doi.org/10.1108/09596110310482209 
Gelbrich, K., \& Roschk, H. (2011). A meta-analysis of organizational complaint handling and customer responses. Journal of Service Research, 14(1), 24-43. http://dx.doi.org/10.1177/1094670510387914

Gilly, M. C., \& Gelb, B. D. (1982). Post-purchase consumer processes and the complaining consumer. Journal of Consumer Research, 323-328. http://dx.doi.org/10.1086/208927

Gronroos, C. (2007). Service management and marketing: customer management in service competition: John Wiley \& Sons.

Gustafsson, A. (2009). Customer satisfaction with service recovery. Journal of Business Research, 62(11), 1220-1222. http://dx.doi.org/10.1016/j.jbusres.2008.11.001

Jacoby, J., \& Jaccard, J. (1981). The sources, meanings and validity of consumer complaint behaviour: A psychological analysis. Journal of Retailing, 57(3), 4-24.

Johnston, R. \& Michel, S. (2008). Three outcomes of service recovery: customer recovery, process recovery and employee recovery. International Journal of Operations \& Production $\quad$ Management, 28, 79-99. http://dx.doi.org/10.1108/01443570810841112

Kanousi, A. (2005). An empirical investigation of the role of culture on service recovery expectations. Managing Service Quality, 15, 57-69. http://dx.doi.org/10.1108/09604520510575263

Karatepe, O. M. \& Ekiz, E. H. (2004). The effects of organizational responses to complaints on satisfaction and loyalty: a study of hotel guests in Northern Cyprus. Managing Service Quality, 14, 476-486. http://dx.doi.org/10.1108/09604520410569810

Kau, A. K. \& Loh, E. W. Y. (2006). The effects of service recovery on consumer satisfaction: a comparison between complainants and non-complainants. Journal of Services Marketing, 101-111. http://dx.doi.org/10.1108/08876040610657039

Keaveney, S. M. (1995). Customer switching behaviour in service industries: an exploratory study. Journal of Marketing, 59, 71-82. http://dx.doi.org/10.2307/1252074

Kelley, S. W., \& Davis, M. A. (1994). Antecedents to customer expectations for service recovery. Journal of the Academy of Marketing Science 22(2), 52-61. http://dx.doi.org/10.1177/0092070394221005

Kelley, S. W., Hoffman, K. D. \& Davis, M. A. (1993). A typology of retail failures and recoveries. Journal of Retailing, 69, 429-452. http://dx.doi.org/10.1016/0022-4359(93)90016-C 
Keng, K. A., Richmond, D. \& Han, S. (1995). Determinants of Consumer Complaint Behaviour. Journal of International Consumer Marketing, 8, 59-76. http://dx.doi.org/10.1300/J046v08n02_05

Kolodinsky, J. (1992). A system for estimating complaints, complaint resolution and subsequent purchases of professional and personal services. Journal of Consumer Satisfaction, Dissatisfaction and Complaining Behavior, 5, 36-44.

Lala, V., \& Priluck, R. (2011). When Students Complain An Antecedent Model of Students' Intention to Complain. Journal of Marketing Education, 33(3), 236252.

Lewis, B. R., \& Spyrakopoulos, S. (2001). Service failures and recovery in retail banking: the customers' perspective. The International Journal of Bank Marketing, 19(1), 37-48. http://dx.doi.org/10.1108/02652320110366481

Mattila, A. S., \& Mount, D. J. (2003). The impact of selected customer characteristics and response time on e-complaint satisfaction and return intent. International Journal of Hospitality Management, 22(2), 135-145. http://dx.doi.org/10.1016/S0278-4319(03)00014-8

Miller, E. G., Kahn, B. E., \& Luce, M. F. (2008). Consumer wait management strategies for negative service events: a coping approach. Journal of Consumer Research, 34(5), 635-648. http://dx.doi.org/10.1086/521899

Minichielo, V., Madison, J., Hays, T., Courtney, M., and St-John, W. (1999). Handbook of Research Methods for Nursing and Health Science, Pearson Education Australia, French Forest, N.S.W.

Mittal, V., Huppertz, J. W., \& Khare, A. (2008). Customer complaining: The role of tie strength and information control. Journal of Retailing, 84(2), 195-204. http://dx.doi.org/10.1016/j.jretai.2008.01.006

Morganosky, M. A., \& Buckley, H. M. (1987). Complaint behaviour: analysis by demographics, lifestyle and consumer values. Advances in consumer research, 14(1), 223-226.

Namkung, Y., Jang, S. C. S., \& Choi, S. K. (2011). Customer complaints in restaurants: Do they differ by service stages and loyalty levels? International Journal of Hospitality Management, 30(3), 495-502. http://dx.doi.org/10.1016/j.ijhm.2010.07.005

Osarenkhoe, A. \& Komunda, M. (2012). Remedy or Cure for Service Failure?: Effects of Service Recovery on Customer Satisfaction and Loyalty. Business Process Management Journal, 18, 82-103.

Patton, MQ. (1990). Qualitative evaluation methods, Sage Publications, inc. 
Ramsey, R. D. (2003). How to handle customer complaints. American Salesman, 48(10), 15-20.

Richins, M., and Verhage, V. (1985). Seeking redress for consumer dissatisfaction: The role of attitudes and situational factors. Journal of Consumer Policy, 18(1), 29-44. http://dx.doi.org/10.1007/BF00380281

Sabharwal, N. \& Soch, H. (2011). Confirmatory Factor Analysis of Determinants of Service Recovery. Global Business Review, 12, 297-318. http://dx.doi.org/10.1177/097215091101200208

Schroefer, K. \& Ennew, C. (2002). Emotional responses to service complaint experiences: the role of perceived justice. Tourism and Travel Research Institute.

Sharma, S., Medury, Y., \& Gupta, A. (2012). Empirical Study of the Attributes of Good Service Recovery. Journal of Biological Chemistry, 1(10).

Siddiqui, M. H., \& Tripathi, S. N. (2010). An analytical study of complaining attitudes: with reference to the banking sector. Journal of Targeting, Measurement and Analysis for Marketing, 18(2), 119-137. http://dx.doi.org/10.1057/jt.2010.2

Singh, J. (1990) Voice, exit, and negative word-of-mouth behaviors: an investigation across three service categories. Journal of the Academy of Marketing Science, 18, 1-15. http://dx.doi.org/10.1007/BF02729758

Smith, A. K., Bolton, R. N. \& Wagner, J. (1999). A model of customer satisfaction with service encounters involving failure and recovery. Journal of Marketing Research, 356-372. http://dx.doi.org/10.2307/3152082

Smith, J. S., Karwan, K. R., \& Markland, R. E. (2012). An empirical investigation of the effectiveness of an integrated service recovery system. Operations Management Research, 1-12. http://dx.doi.org/10.1007/s12063-012-0063-0

Taylor, S. (1994). Waiting for service: the relationship between delays and evaluations of service. The Journal of Marketing, 56-69. http://dx.doi.org/10.2307/1252269

Tax, S. S., Brown, S. W. \& Chandrashekaran, M. (1998). Customer evaluations of service complaint experiences: implications for relationship marketing. The Journal of Marketing, 60-76. http://dx.doi.org/10.2307/1252161

Tsarenko, Y., \& Strizhakova, Y. (2012). Coping With Service Failures: The Role Of Emotional Intelligence, Self-Efficacy And Intention To Complain. European Journal of Marketing, 47(1/2), 4-4. http://dx.doi.org/10.1108/03090561311285466

Vázquez, R., Suárez, L., \& Díaz, A. M. (2010). Perceived justice of service recovery strategies: Impact on customer satisfaction and quality relationship. Psychology \& Marketing, 27(5), 487-509. 
Weun, S., Beatty, S. E. \& Jones, M. A. (2004). The impact of service failure severity on service recovery evaluations andpost-recovery relationships. Journal of Services Marketing, 18, 133-146. http://dx.doi.org/10.1108/08876040410528737

Wirtz, J., \& Mattila, A. S. (2004). Consumer responses to compensation, speed of recovery and apology after a service failure. International Journal of service industry management, 15(2), 150-166. http://dx.doi.org/10.1108/09564230410532484

Yanamandram, V., and White, L. (2006). Switching barriers in business-to-business services: A qualitative study. International Journal of Service Industry Management, 17(2), 158-192. http://dx.doi.org/10.1108/09564230610656980

Younas, A. \& Jan, H. 2012. The Impact of Service Recovery on Customer Loyalty (Case company: Swedbank). PhD Doctoral, University of Gävle.

Zhou, Y., Tsang, A. S. L., Huang, M. \& Zhou, N. (2012). Does delaying servicefailure resolution ever make sense? Journal of Business Research. http://dx.doi.org/10.1016/j.jbusres.2012.10.009 
